Innlegg på inntil 400 ord lastes opp i http://mc.manuscriptcentral.com/tidsskriftet.

Redaksjonen forbeholder seg retten til å foreta redaksjonelle endringer.

Forfattere av vitenskapelige artikler har automatisk tilsvarsrett (jf. Vancouver-gruppens regler).

\section{Pasientforståelse viktig for valg av navn}

I Tidsskriftet nr. 24/2009 ønsker Petter Gjersvik debatt om navnevalg, symboleffekter, kompetanseutvikling og fremtidig omdømme når ulike avdelinger og fagområder slås sammen til

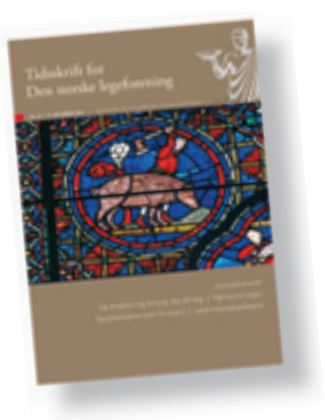
én organisatorisk enhet (1). Endringer i etablerte medisinske strukturer medfører ofte bekymringer og er ikke fritt for maktkamper. Når det gjelder hvilke fagområder som hører sammen, kan dette sikkert betraktes fra mange ulike synsvinkler. Navnevalg har ofte stor symbol- og identitetsverdi for fagfolk, men navnene bør også være forståelige for pasientene. Dersom man primært henvender seg til pasienter, bør kanskje norske betegnelser velges og avdelingen kunne kalles «Avdeling for revmatiske-, hud og infeksjonssykdommer». Da favner man ikke for vidt. Begrepene «veneriske sykdommer» og «klinisk immunologi» må imidlertid lide - dette er betegnelser som trolig er noe fremmede for pasienter. Dersom de enkelte fagområders og fagpersoners identitet er viktig, burde man kanskje ha valgt betegnelsen «Avdeling for revmatologi, dermatologi og (klinisk) immunologi».

Selv om både navnevalg og strukturendringer vekker følelser og oppleves som vanskelig, virker ledelsen imøtekommende i dette tilfellet: De har lovet evaluering av både navn og struktur i løpet av 2010. Det gir muligheter for å evaluere sammenslåingen og eventuelt justere kursen. Da kan også bekymringer rundt navnevalget og om det over tid vil signalisere lavkompetanse, bli satt på agendaen. Så lenge avdelingen satser på kunnskapsbasert kompetanse, gode pasientmøter og forskning og prioriterer nødvendig omdømmebygging, ville jeg ikke vært altfor bekymret for de tre fagenes fremtid sammen.

To av fagområdene har til en viss grad ansvar for beslektede sykdommer med basis i immunologiske mekanismer. Hud og revmatologi har også en del felles utfordringer når det gjelder bruk av de såkalte biologiske legemidler. Et slikt delvis felles medisinsk grunnlag burde anspore den nye avdelingen til å utnytte muligheter og potensielle fortrinn til å vektlegge immunologiske sykdommer. Sammenslåing av fagområder med større medisinske og kulturelle ulikheter kan føre til en enda mer konstruert og komplisert virkelighet.

\section{Erik Rødevand}

St. Olavs hospital

\section{Litteratur \\ 1. Gjersvik P. Når ulike avdelinger slås sammen til en stor. Tidsskr Nor Legeforen 2009; 129: 2667.}

\section{Partsinnlegg om svak stråling og helse}

Inspirert av Arnt Inge Vistnes' utvidede og kritiske omtale (1) av Walter Kraus' Mobilstråling (2) ble jeg nysgjerrig på hva den egentlig inneholder. Jeg leste den med interesse, med bakgrunn som ikke-fagmann på området.

Det faglige miljøet er delt i synet på svak ikke-ioniserende stråling. På den ene siden befinner seg en majoritet av forskere og deres støttespillere i helsebyråkratiet som mener at det ikke foreligger tilstrekkelig dokumentasjon på helseeffekter av slik strålepåvirkning. På den andre siden står en rekke forskere fra mange land, fagfolk, leger og personer i miljøorganisasjoner og pasientorganisasjoner. Denne fløyen hevder at selv om kunnskapsgrunnlaget ikke er entydig og det opplagt trengs mer forskning, finnes det likevel tilstrekkelig dokumentasjon på at svak stråling innebærer risiko for biologiske prosesser og helsen vår. Denne gruppen argumenterer for å etablere nye og strengere grenseverdier, slik det allerede er gjort $i$ en rekke land.

I dette faglige brytningsfeltet befinner Vistnes seg i majoritetsgruppen av forskere, mens den tyskutdannede bygningsbiologen Kraus tilhører mindretallet som er kritisk til dagens grenseverdier. Vistnes skriver at Kraus har presentert et partsinnlegg for sitt syn, men denne karakteristikken gjelder i like stor grad hans egen anmeldelse.

Kraus har rundt 25 års erfaring på feltet og mener å ha hjulpet en rekke eloverfølsomme. Slik erfaringsbasert kunnskap er viktig å få frem. Jeg er sikker på at mange norske leger og helsearbeidere vil ha stor interesse av å lese dette, enten man er enig med Kraus eller ikke. Kraus skriver også greit om stråling i de miljøene hvor vi oppholder oss mest (bolig, arbeidsplass), og hva som kan gjøres for å redusere stråleeksponeringen. I tillegg har han en lett forståelig innføring i den svake strålingens fysikk som de fleste ikke-fagfolk vil ha utbytte av.

Det kanskje mest tankevekkende og viktige stoffet i Mobilstråling handler om sentrale samfunnsmessige og politiske aspekter omkring svak stråling og helse, inkludert barn og trådløs teknologi, juridiske aspekter omkring slik eksponering («et juridisk ingenmannsland») og risikovurderinger i vitenskap og politikk.

Vistnes konkluderer at boken «er for spesiell og for ensidig og har for mange feil til å være interessant». Feilene er selvsagt beklagelige, og det er som forventet at en fagmann som Vistnes fra motsatt leir ikke finner den interessant som fagbok. Som ikke-fagmann finner imidlertid jeg den meget engasjerende.

Radiofrekvent stråling, som mikrobølger, har økt dramatisk i omfang og intensitet de siste tiårene. I et evolusjonært perspektiv representerer slik stråling eksponering for nye miljøfaktorer for mennesket. Manglende kunnskap om eventuelle helseskadelige effekter av dette samt mulig iverksetting av tiltak etter føre var-prinsippet er derfor problemstillinger vi bør følge nøye. Kraus' bok gir etter min mening et interessant bidrag til denne debatten. Her har leserne en god mulighet til å få innblikk $i$ et gjennomtenkt partsinnlegg fra den fagkritiske fløyen.

\section{Iver Mysterud}

Biologisk institutt

Universitetet i Oslo

\section{Litteratur}

1. Vistnes Al. Tendensiøst om stråling. Anmeldelse av: Mobilstråling. Tidsskr Nor Legeforen 2009: 129: $2510-1$.

2. Kraus W. Mobilstråling. Oslo: Spartacus, 2009. 